\title{
EVALUATION OF GOOD GOVERNANCE IN EU COUNTRIES
}

\author{
[Hodnocení dobré veřejné správy v zemích EU]
}

\author{
Eva Ardielli ${ }^{1}$, Martina Halásková ${ }^{2}$ \\ ${ }^{1}$ Vysoká škola báňská-Technická univerzita Ostrava, Ekonomická fakulta, Sokolská 33, 70121 Ostrava \\ Email:eva.ardielli@vsb.cz. \\ ${ }^{2}$ Vysoká škola báňská-Technická univerzita Ostrava, Ekonomická fakulta, Sokolská 33, 70121 Ostrava \\ Email:martina.halaskova@vsb.cz
}

\begin{abstract}
The paper is focused on the evaluation of the level of governance from the perspective of Good Governance concept in the European Union countries. Research of the state of governance in the EU countries is based on the evaluation of Good Governance indicators defined by the World Bank. These are the aggregate indicators characterizing the quality of democracy, political stability, government effectiveness, regulatory quality, quality of legal system and corruption, which in whole describe the state of Good Governance. On their basis, there is calculated the composite index of Good Governance. The composite index of Good Governance is observed in the period from 1996 to 2013 for the selected groups of the European Union countries. In the empirical part of the paper, there is evaluated the actual state of Good Governance in the EU countries in 2013 and compared the state and progression of Good Governance in the European Union countries in the years 1996 and 2013. The research is based on soft data, since most of the data for the evaluation of Good Governance have qualitative nature. The research results especially indicate the excellent state of governance in the Nordic countries and also acknowledge the convergence of the level of governance in the EU countries.
\end{abstract}

Keywords: composite index, EU countries, evaluation, Good Governance, individual aggregate indicators.

JEL classification: H11, H83

Doručeno redakci: 22.7.2015; Recenzováno: 4.8.2015; 11.8.2015; Schváleno k publikování: 15.12.2015

\section{Introduction}

Currently, there is as a part of the management and public affairs administration significantly promoted the concept of Good Governance. This concept has its foundations in the Governance school of thought, which is based on the approach of „activating state“, as described in Žárska et al. (2010, p. 27). This approach provides in accordance with its principles of public administration functioning space for cooperation of public administration with environment, society and economy. Wohlfhrt and Zühlke (2005, p. 70) characterize Good Governance as a concept that supports the connection of state, private, formal and informal partners to create cooperative relationships between them. This concept has been significantly promoted since the mid-90s of the 20th century and remains at the forefront, see Jann (2006).

The idea of Good Governance describes the high-quality and properly functioning public administration with integrated element of subsidiarity, allowing the participation of citizens and respecting democratic values and rules of a modern state. Moreover, it highlights the potential of combination of different management approaches, brings an element of sociopolitical coordination through networks and supports diversity of stakeholders in the interaction processes as further specified by Klenk and Nullmeier (2003), Kickert et al. (1997), Kooiman (2003), Roy and Tisdell (1998), Zanger (2000). 
The fundamental change and benefit of Good Governance in contrast with the previous attitude to the development of public administration is the fact that the public sector organizations can be seen no longer as static and unchanging, but as the living organisms, see Frič (2008). As reported by Potůček (2005) the state is also shifted from the role of dominance to partnership, it is also defining the field in which his authority cannot be effectively replaced by any other actor. The result of this development is the need for internal reforms in the public administration system and principles on which the state is built and the need to create more professional, better quality and better functioning public administration. Thus, the state can, through new partners and new rules achieve greater efficiency, even giving up a part of its roles and responsibilities, see Potůček, Musil and Mašková (2008).

The aim of this paper is to evaluate the state and progression of Good Governance in the EU member states, based on indicators of Good Governance and to verify whether the level of governance in the EU is increasing. The aim of the research is supported by verifying the hypothesis whether the convergence of Good Governance level occurs in selected EU countries in long term period.

The paper is divided into theoretical and empirical parts. In the theoretical part there is provided the theoretical basis of Good Governance concept, the principles of Good Governance and importance of the concept in the context of international politics. Further, there is described the methodology including the process of solution, methods and data sources. In the empirical part, there are summarized the results of Good Governance assessment in the EU countries, based on indicators of Good Governance. Results include the evaluation of the current state of Good Governance and also the long-term development of the level of Good Governance in the EU. In conclusion, there are summarized and commented the achieved results and verified the hypothesis.

\section{Theoretical definition of the Good Governance concept}

The concept of Good Governance is not at the national or international level legislatively defined. Documents dealing with this issue define Good Governance through its individual components; known as principles of Good Governance, see Potěšil (2008). The concept of Good Governance is one of the contemporary current trends of public administration modernization. As reported by Klimovský (2010), the applying of the Good Governance concept is also promoted by international, multinational and national subjects such the World Bank, UN, IMF, OECD, EU or Council of Europe. With regard to the fact that the proper performance of administrative practice stands in the focus of interest of many multinational and international organizations, the concept of Good Governance is described in a number of important documents with international scope. E.g. the World Bank defines Good Governance in the project "Worldwide Governance Indicators" (WGI), see World Bank (2014). Governance here is defined as traditions and institutions by which is exercised the power in the country. Good Governance is described as a set of three interrelated aspects, which include:

- Process of selection, monitoring and replacement of governments,

- ability of the government to effectively formulate and implement suitable policies,

- and respect of citizens and the state to institutions that determine the socio-economic environment in the country.

The crucial role in shaping the concept of Good Governance has been played by the Council of Europe, which analyzes the individual partial aspects of proper performance of public administration in several different acts. Despite the fact that these acts in the form of 
recommendations and resolutions are not legally binding, states have at least a political commitment to act in accordance with them.

Comprehensive look at the issue of Good Governance is mostly available in the "Council of Europe Recommendation on good administration" from 2007, see Council of Europe (2007), which aims to define the basic right to good administration and to facilitate its effective implementation in practice. Good Governance is according to this recommendation the aim, which should be achieved and maintained. Public administration, which has to be Good Governance, is the reflection of quality, clear, transparent and understandable legislation. It must also meet the basic need of society to participate administration, while despite its publicly-power nature must be based on the need to balance and protect the rights of individuals. For this reason, the great importance is placed on quality control and efficiency of public administration and the further deepening of Good Governance, as stated by Potěšil (2008). Good Governance is then in the sense of Supplement to the Council of Europe Recommendation from 2007 defined through its individual components, known as the principles of Good Governance, see Table 1.

Table 1: Characteristics of Good Governance principles by the Council of Europe

\begin{tabular}{|c|c|}
\hline $\begin{array}{l}\text { Principles of Good } \\
\text { Governance }\end{array}$ & Characteristic \\
\hline Principle of lawfulness & $\begin{array}{l}\text { The basic principle is the principle of legality, which obliges public authorities } \\
\text { act only within the limits of the law and on the basis of their powers defined. } \\
\text { This principle gives certainty to subjects of public administration, which can } \\
\text { rationally expect the obligations fulfilment of administrative bodies and also } \\
\text { the consequences when failure to comply their own obligations. }\end{array}$ \\
\hline Principle of equality & $\begin{array}{l}\text { Administrative authorities are acting with private entities in the same cases } \\
\text { straight and objectively. When in similar situations occur the differences in } \\
\text { approach, there must be a rational justification. Discrimination among subjects } \\
\text { is inadmissible. }\end{array}$ \\
\hline Principle of impartiality & $\begin{array}{l}\text { Officials should act impartially and only with regard to the case. To relate to } \\
\text { the public should not enter their own interests, beliefs or partiality. }\end{array}$ \\
\hline Principle of proportionality & $\begin{array}{l}\text { The administrative authority may interfere in the rights acquired in good faith } \\
\text { only under conditions set by law and to the extent necessary to achieve the } \\
\text { desired goals. According to the principle of proportionality should be } \\
\text { maintained proportionality among various rights. }\end{array}$ \\
\hline Principle of legal certainty & $\begin{array}{l}\text { Rights engendered of public law shall not be violated. The exception may be } \\
\text { only because of the need to change the public interest. Unmeritorious claims } \\
\text { and retroactive duties shall not be implemented and enforced. }\end{array}$ \\
\hline $\begin{array}{l}\text { Principle of taking action } \\
\text { within a reasonable time } \\
\text { limit }\end{array}$ & $\begin{array}{l}\text { Public authorities should fulfil their tasks within a reasonable period of time } \\
\text { commensurate with the task. They should avoid unnecessary and unwarranted } \\
\text { time delays. }\end{array}$ \\
\hline Principe of participation & $\begin{array}{l}\text { Private persons have the opportunity to participate in the preparation and } \\
\text { implementation of administrative decisions affecting their rights and interests. } \\
\text { They have the opportunity to consult the files concerning them and to } \\
\text { comment on the decision. }\end{array}$ \\
\hline $\begin{array}{l}\text { Principle of respect for } \\
\text { privacy }\end{array}$ & $\begin{array}{l}\text { This principle plays an important role, especially in recent years, when the } \\
\text { great importance is placed on the protection of fundamental rights and } \\
\text { freedoms. According to this principle should be protected personal data, and } \\
\text { the officials should handle them with respect to privacy. }\end{array}$ \\
\hline Principle of transparency & $\begin{array}{l}\text { Public authorities publish their decisions, inform private persons by publishing } \\
\text { official documents and other appropriate information means. At the same time } \\
\text { they respect the protection of privacy and personal data and don't disclose } \\
\text { information of private persons, where it is rejected by the law. }\end{array}$ \\
\hline
\end{tabular}

Source: Council of Europe: Recommendation CM/Rec (2007)7 of the Committee of Ministers to member states on good administration [online] [vid. 25. May 2015]. Available from: wcd.coe.int/ViewDoc.jsp?id=1155 877; own processing 
The principles of Good Governance are also formulated in the documents of other major organizations such as the OECD, the UN or the EU. Some of the documents state the specific enumeration of principles; certain principles can be only inferred based on them. There is no uniform naming of principles, however, they identically define the basic requirements on Good Governance. The principles of Good Governance although they are not strictly defined and their performance is not enforceable are widely accepted and incorporated into the variety of important international documents. Their reflection in national legislation and implementation is therefore expected within the member countries. The EU strongly supports the concept of Good Governance and supports the increasing of quality of public administration, as it is considered as the key aspect in ensuring a country's long-term competitiveness and well-being. Therefore the quality improving of public administration has been an important funding objective of the European structural investments in several member states, see European Commission (2014). According to Lacina (2010), the application of Good Governance in European public administration systems is affected mainly due to effects of severe economic and financial factors, the application of the principles of strategic planning and the formulation of ideas about the goals of reform and ways of their implementation, and to some extent also efforts to develop the European Administrative Space. Good Governance is also the subject of a number of research studies that pay attention e.g. to the modern forms of governance in a research project of the University of Economics, Faculty of International Relations (VŠE, 2007-2013), the public administration reform in member countries (Ladi, 2008) or the value of Good Governance (Arturo and Cantale, 2012).

\section{Methodology}

The empirical part of the paper is based on processing and evaluation of data collected by the World Bank. Assessing of the state of Good Governance is performed in all EU countries (EU-28). To verify the hypothesis, the specific research was carried out on the sample of EU countries. These were the original EU countries (so-called EU-15) and accessing countries in 2004 (so-called EU-10), or the set of countries EU-25 (including the original EU-15 countries and EU-10 countries). Evaluation of Good Governance is done with the use of comparative and graphical methods. The list of the categories of EU country groups is described in Tab. 2 .

Table 2: Summary of the EU country groups

\begin{tabular}{|c|c|c|c|c|c|}
\hline EU enlargement & $\begin{array}{l}\text { Year of } \\
\text { accession }\end{array}$ & Country & \multicolumn{3}{|c|}{ The EU country groups } \\
\hline Foundation & 1952 & $\begin{array}{l}\text { Belgium (BE), France (FR), Germany (DE), } \\
\text { Italy (IT), Luxembourg (LU), Netherlands } \\
\text { (NL) }\end{array}$ & \multirow{5}{*}{ EU-15 } & \multirow{6}{*}{ EU-25 } & \multirow{8}{*}{ EU-28 } \\
\hline 1. enlargement & 1973 & $\begin{array}{l}\text { Denmark (DK), Ireland (IE), United Kingdom } \\
\text { (UK) }\end{array}$ & & & \\
\hline 2. enlargement & 1981 & Greece (EL) & & & \\
\hline 3. enlargement & 1986 & Portugal (PT), Spain (ES) & & & \\
\hline 4. enlargement & 1995 & Austria (AT), Finland (FI), Sweden (SE) & & & \\
\hline 5. enlargement & 2004 & $\begin{array}{l}\text { Czech Republic (CZ), Estonia (EE), Cyprus } \\
\text { (CY), Latvia (LV), Lithuania (LT), Hungary } \\
\text { (HU), Malta (MT), Poland (PL), Slovakia } \\
\text { (SK), Slovenia (SI) }\end{array}$ & EU-10 & & \\
\hline 6. enlargement & 2007 & Bulgaria (BG), Romania (RO) & & & \\
\hline 7. enlargement & 2013 & Croatia (HR) & & & \\
\hline
\end{tabular}

Source: Europa: Jednotlivé země 2015 [online] [vid. 2. May 2015]. Available form: europa.eu/abouteu/countries/index_cs.htm, own processing

In our research there was used for evaluation of Good Governance the approach of the World Bank. The World Bank has been collecting data for the broad international comparison since 
1996 and currently they have been monitored annually. It processes indicators of governance for 215 economies of the world, closer Kaufmann, Kray and Mastruzzi (2006). Good Governance is monitored on the basis of six aggregate indicators, so called WGI. These aggregate indicators combine the views of a large number of businesses, citizens and experts in both developed and developing countries. They are based on 32 individual data sources produced by various international organizations, academic institutions, NGOs and private companies.

\subsection{Input data and data processing}

Analysis of Good Governance is based on World Bank data on Good Governance, see the World Bank (2014), which are soft data, obtained mainly through expert investigations. Most indicators of public administration quality is qualitative in nature, and therefore cannot be obtained in the form of usual available hard (statistical) data. The disadvantage of these soft data is the possibility of assessment distortion in the connection with the current economic situation in a country. Level of governance in EU countries in the selected period is evaluated on the basis of changes in indicators of Good Governance. Data for comparison are available from 1996 to 2013, while from 1996 to 2004, the indicators were monitored only every two years. From 2004 they have been monitored annually. The advantage is that the data are obtained and processed all the time with the same method and are thus comparable to each other. In the research there are processed data from 1996 to 2013 for the EU-28 countries. The data source for comparing is the database of the World Bank based on the output of the project WGI referred above measuring the quality of governance. This data were chosen because they characterize the public administration in terms of quality and because of geographic coverage and long-term monitoring that enable international comparisons over time. There are evaluated six characteristics of governance, so-called aggregate indicators of Good Governance, see Tab. 3.

Table 3: Aggregate indicators of Good Governance

\begin{tabular}{|l|l|}
\hline Aggregated indicator & Characteristic \\
\hline Voice and Accountability & $\begin{array}{l}\text { Assesses the extent of democracy on the basis of the characteristics of the } \\
\text { political process, civil liberties, political rights and independence of the } \\
\text { media. }\end{array}$ \\
\hline $\begin{array}{l}\text { Political Stability and Absence } \\
\text { of Violence }\end{array}$ & $\begin{array}{l}\text { Assesses the probability of destabilizing the authority of government or its } \\
\text { overthrow, including the threat of terrorism. }\end{array}$ \\
\hline Government Effectiveness & $\begin{array}{l}\text { Government performance is evaluated according to the prerequisites for } \\
\text { formulating and implementing appropriate policies. These assumptions } \\
\text { include the provision of quality public services, the quality of the } \\
\text { bureaucracy, the competence of officials, authorities' independence from } \\
\text { political pressures and the credibility of the government in implementing } \\
\text { of the proclaimed policies. }\end{array}$ \\
\hline Regulatory Quality & $\begin{array}{l}\text { Evaluates the policies in terms of interventions distorting markets } \\
\text { functionality and in terms of over-regulation in foreign trade and business. }\end{array}$ \\
\hline Rule of Law & $\begin{array}{l}\text { The quality of the legal system is evaluated by the trust in the rules of } \\
\text { society and the degree of respect for them. This indicator expresses the } \\
\text { perception of the incidence of violent and non-violent crime, the } \\
\text { effectiveness and predictability of court decisions and the enforcement of } \\
\text { contracts. }\end{array}$ \\
\hline Control of Corruption \\
phis indicator measures perceptions of corruption, defined as the use of \\
\hline
\end{tabular}

Source: World Bank: Worldwide Governance Indicators 2014 [online] [vid. 25. May 2015]. Available from: info.worldbank.org/governance/wgi/index.aspx\#home, own processing 
Each of the aggregate indicators becomes normalized values in the interval from -2.5 (worst result) to 2.5 (best result). Evaluation of Good Governance in the EU-28 countries is based on the comparison of the level of public administration according to the composite index of Good Governance, similarly to Žák (2005), which is constructed on the basis of the above mentioned aggregate indicators as the arithmetical average, see (1).

$$
\bar{x}=\frac{1}{n}\left(x_{1}+x_{2}+\ldots+x_{n}\right)=\frac{1}{n} \sum_{i=1}^{n} x_{i}
$$

Where $\bar{x}$ is the composite index of Good Governance, $n$ is the number of aggregate indicators and $x_{i}$ are the results of individual aggregate indicators.

Calculation of the composite index was performed separately for each country and year and for each of the selected groups of EU countries (EU-10, EU-15, EU-25 and EU-28).

\section{Results and discussion}

In this part of the paper there are presented results of the research in the EU countries devoted to the state and progression of Good Governance. The results are divided into two outcomes:

- Evaluation of the trend of Good Governance advancement in selected EU countries and the evaluation of the current state of Good Governance in the EU according to the composite index of Good Governance

- and comparison of individual aggregate indicators of Good Governance in selected EU countries in 1996 and 2013.

\subsection{Evaluation of the development and state of Good Governance in the EU}

Due to the fact that the World Bank (2014) has been monitoring the values of the aggregate indicators since 1996, it is possible to detect the basic trends of the composite index of Good Governance for individual countries and groups of countries. In Fig. 1 there is shown the development of the composite index in the EU-28, EU-25, EU-15 and EU-10 countries from 1996 to 2013.

Figure 1: Comparison of Good Governance progression in EU country groups (1996 - 2013)

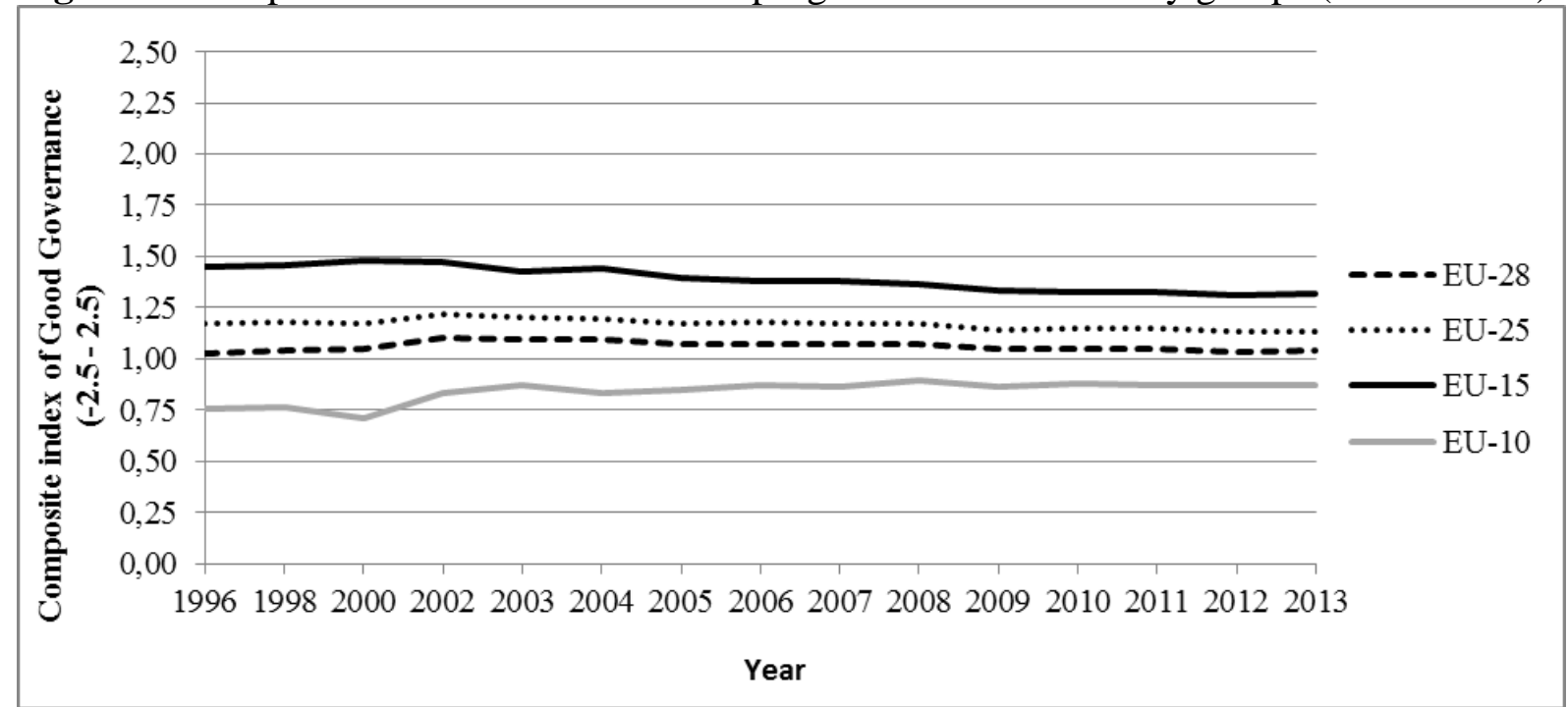

Source: World Bank: Worldwide Governance Indicators 2014 [online] [vid. 25. May 2015]. Available from: info.worldbank.org/governance/wgi/index.aspx\#home; own calculations from 2015 
Based on the comparison of the composite index of Good Governance in the years 1996 to 2013 in particular groups of EU countries, it is possible to trace two tendencies. While in the EU-10 countries the trend of gradual improvement of the level of governance is evident, at the EU-15 countries the trend is reversed. This trend is also reflected in the values of EU-25 and EU-28.

Fig. 2 summarizes the results of the evaluation of Good Governance in the EU by composite index in the year 2013. There are also included the results of selected EU country groups (the EU-15, EU-25, EU-28 and EU-10 countries).

Figure 2: Evaluation of Good Governance state in the EU countries (2013)

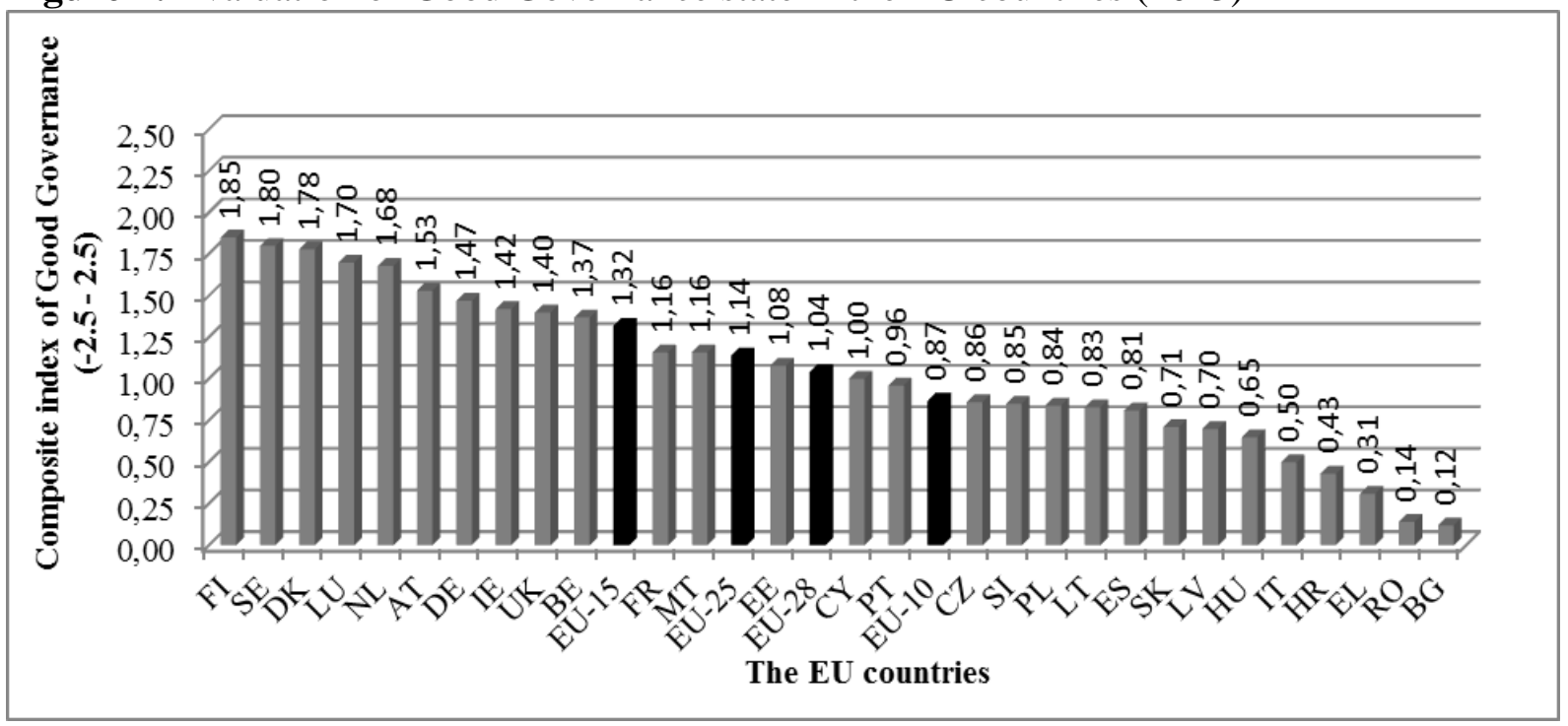

Source: World Bank: Worldwide Governance Indicators 2014 [online] [vid. 25. May 2015]. Available from: info.worldbank.org/governance/wgi/index.aspx\#home; own calculations from 2015

The assessment shows that the composite index of Good Governance in the EU countries has only positive values in the interval from 0.12 to 1.85 . Top ranked countries are the Nordic countries: Finland, Sweden and Denmark. This confirms the fact that the Scandinavian administrative systems are characterized by high performance, high degree of openness and transparency, legislative and sophisticated control system, high prestige of key public institutions and civil services and minimum levels of corruption in public administration, compare with (Halásková and Halásková, 2015, p. 54). On the contrary, as it is evident from Fig. 2, the worst score was reached by Greece, Romania and Bulgaria. Comparison among the EU countries is refined by adding of the EU country groups averages.

The EU-15 average is better placed than the EU-10 average, which shows that after the eastern enlargement in 2004 the level of governance in the EU-25 countries decreased. Also, the average of the EU-28 countries achieved lower score than the EU-25 average, which points to further reduce of the level of governance in the EU-28 countries after the accession of Bulgaria, Romania and Croatia. This fact can be partly explained by the lower level of the economies in these countries, which is connected with the higher level of corruption. Furthermore, there can be seen shortcomings in the functioning of the political system, key institutions of public administration in the legislative ensuring, control system and the small prestige of public servants and public service system.

Based on the results it is possible to perform the dividing of countries into several groups. Above the EU-15 countries average there are countries with high level of government, and 
therefore may have inspirational character for other EU member states. Countries that are between the EU-15 and EU-10 average have significantly lower level of government than the countries reaching the higher score than the EU-15 average. For example the difference of composite index between Belgium and France is -0.21 . Countries whose score is below the EU-10 average belong to the group of countries with insufficient level of government. The results of the division of the EU countries into five groups according to the composite index of Good Governance are documented in Tab. 4.

Table 4: Grouping of the EU countries by the level of Good Governance (2013)

\begin{tabular}{|l|l|l|}
\hline Group & Type & List of countries \\
\hline 1. group & Leading countries & Finland, Sweden, Denmark \\
\hline 2. group & Countries above average & $\begin{array}{l}\text { Luxembourg, Netherlands, Austria, Germany, Ireland, Great } \\
\text { Britain, Belgium }\end{array}$ \\
\hline 3. group & Average countries & France, Malta, Estonia, Cyprus, Portugal \\
\hline 4. group & Below average countries & $\begin{array}{l}\text { Czech Republic, Slovenia, Poland, Lithuania, Spain, Slovakia, } \\
\text { Latvia, Hungary, Italy, Croatia, Greece }\end{array}$ \\
\hline 5. group & Lagging countries & Romania, Bulgaria \\
\hline
\end{tabular}

Source: World Bank: Worldwide Governance Indicators 2014 [online] [vid. 25. May 2015]. Available from: info.worldbank.org/governance/wgi/index.aspx\#home; own calculations in MS Excel from 2015

The comparison of the state of Good Governance based on the values of the composite index of Good Governance in the EU-10 countries in the years 1996 and 2013 are shown in Tab. 5. Countries are sorted from best to worst index values in 1996 and 2013. In the EU-10 countries occurred in period 1996 and 2013 the improvement of the level of governance on average by $15 \%$.

Table 5: Evaluation of Good Governance in EU-10 countries according to composite index

\begin{tabular}{|l|l|l|l|}
\hline Countries ranking (EU-10) & Year 1996 & Countries ranking (EU-10) & Year 2013 \\
\hline Slovenia & 1,13 & Malta & 1,16 \\
\hline Cyprus & 1,07 & Estonia & 1,08 \\
\hline Malta & 0,99 & Cyprus & 1,00 \\
\hline Czech Republic & 0,86 & Czech Republic & 0,86 \\
\hline Hungary & 0,84 & Slovenia & 0,85 \\
\hline Poland & 0,73 & Poland & 0,84 \\
\hline Estonia & 0,65 & Lithuania & 0,83 \\
\hline Lithuania & 0,52 & Slovakia & 0,71 \\
\hline Slovakia & 0,51 & Latvia & 0,70 \\
\hline Latvia & 0,24 & Hungary & 0,65 \\
\hline
\end{tabular}

Source: World Bank: Worldwide Governance Indicators 2014 [online] [vid. 25. May 2015]. Available from: info.worldbank.org/governance/wgi/index.aspx\#home; own calculations from 2015

While in 1996 Slovenia was at the first place among the EU-10 countries with the value of composite index of Good Governance of 1.13, in 2013 Malta took first place with a slightly higher value of composite index of Good Governance of 1.16. Conversely, Latvia occupied the last place in 1996 with a value of composite index of 0.24. In 2013 Hungary placed on the last position in the achieved level of government from the EU-10 countries. But the value of composite index of the country with the worst level of government of the EU-10 countries rose to 0.65 . This fact is also proved by other studies devoted to the overall evaluation of the competitiveness of the EU countries, where one of the partial indicators is index of governance evaluation, World Economic Forum (2014). 


\subsection{Evaluation of the progression of aggregate indicators in the EU}

The comparison among the EU country groups according to individual aggregate indicators of Good Governance in 2013 is shown in Fig. 3. There is obvious significant difference in the state of public administration in the old EU-15 countries and the Eastern EU-10 countries. The only indicator in which the EU-15 and EU-10 countries are equal is "Political stability". All other indicators in the EU-10 countries show significant deficit in comparison with the EU-15 countries. The most noticeable difference is in the value of the indicator "Control of Corruption". Values of indicators for the EU-28 countries are even lower than for the EU-25 countries, which is caused by the accession of countries with low level of governance into the EU, namely Romania, Bulgaria and Croatia.

Figure 3: Evaluation of aggregate Good Governance indicators in EU country groups (2013)

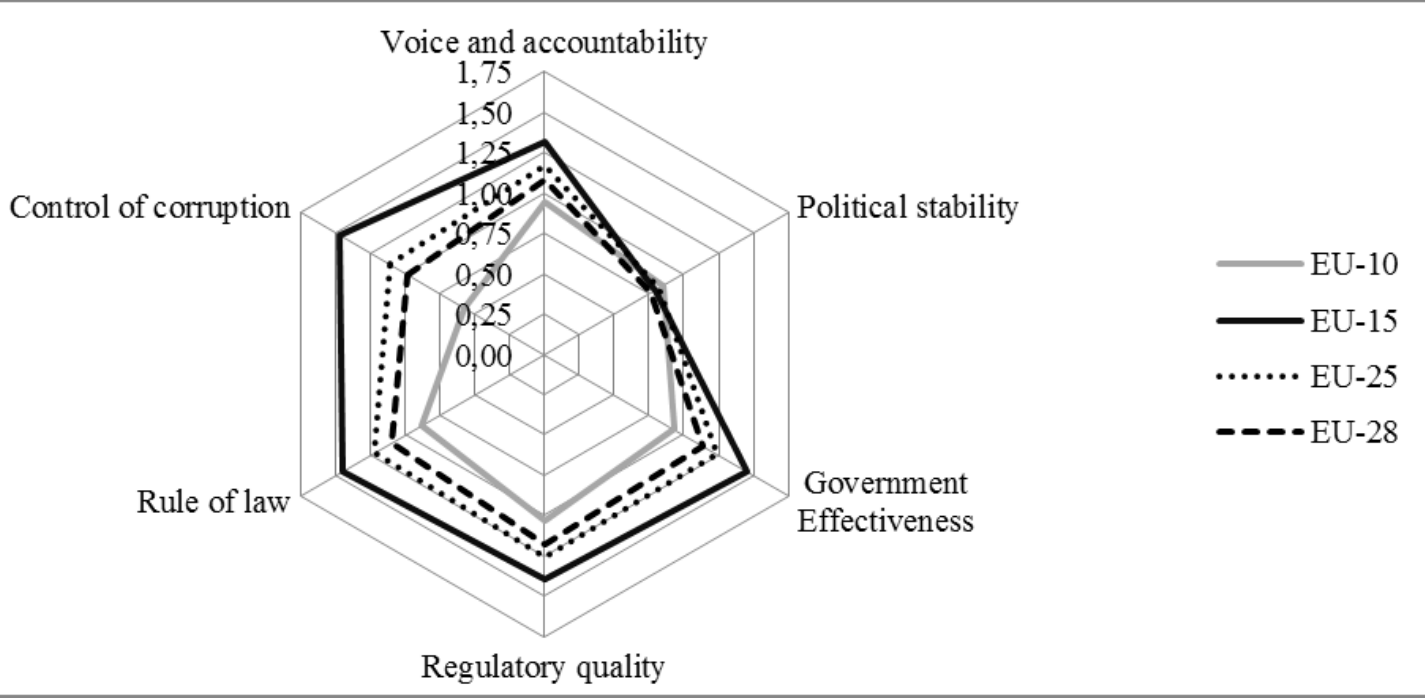

Source: World Bank: Worldwide Governance Indicators 2014 [online] [vid. 25. May 2015]. Available from: info.worldbank.org/governance/wgi/index.aspx\#home; own calculations from 2015

Based on the comparison of aggregate indicators values in the years 1996 and 2013 in the EU10 and the EU-15 countries, it is possible to observe the convergence process of both EU country groups in terms of Good Governance. The state in the year 1996 is shown in Fig. 4.

Figure 4: Evaluation of aggregate Good Governance indicators in EU country groups (1996)

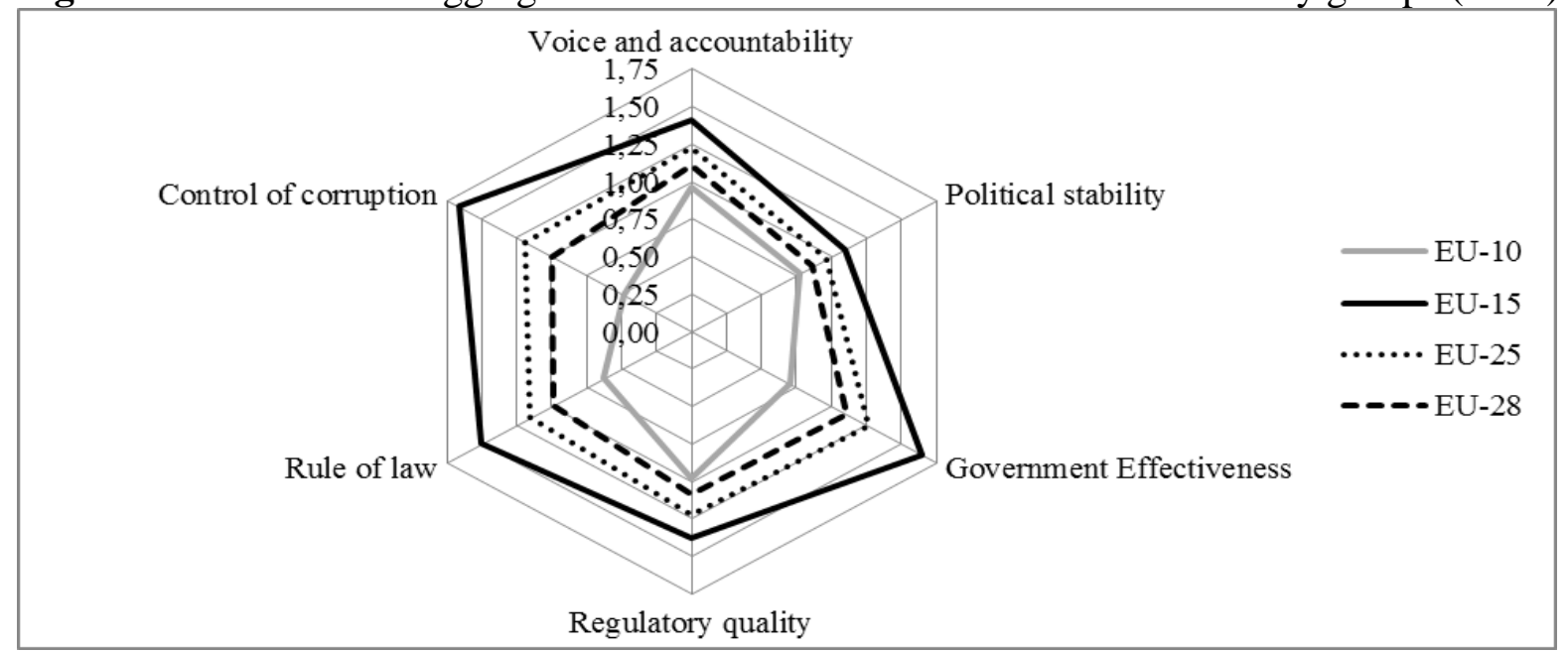

Source: World Bank: Worldwide Governance Indicators 2014 [online]. [vid. 25. May 2015]. Available from: info.worldbank.org/governance/wgi/index.aspx\#home; own calculations from 2015 
The EU-15 countries show decreasing trend in the monitored period, especially in the areas of "Political stability", "Control of corruption" and "Government effectiveness", while the area of "Voice and accountability", "Regulatory quality" and "Rule of law" remained approximately the same level. The EU-10 countries show increasing trend, especially in the areas of "Rule of law" and "Government effectiveness", see in Tab. 6.

Table 6: Evaluation of Good Governance progression in the EU-15 and EU-10 countries

\begin{tabular}{|l|c|l|c|}
\hline EU-15 & $\begin{array}{c}\text { Decrease / increase in } \\
\text { years 1996-2013 in } \%\end{array}$ & EU-10 & $\begin{array}{c}\text { Decrease / increase in } \\
\text { years 1996-2013 in } \%\end{array}$ \\
\hline Voice and accountability & $-6,03$ & Voice and accountability & $-1,62$ \\
\hline Political stability & $-27,56$ & Political stability & 10,49 \\
\hline Government Effectiveness & $-11,97$ & Government Effectiveness & 34,49 \\
\hline Regulatory quality & 1,45 & Regulatory quality & 5,69 \\
\hline Rule of law & $-3,16$ & Rule of law & 34,87 \\
\hline Control of corruption & $-11,63$ & Control of corruption & 15,54 \\
\hline
\end{tabular}

Source: World Bank: Worldwide Governance Indicators 2014 [online] [vid. 25. May 2015]. Available from: info.worldbank.org/governance/wgi/index.aspx\#home; own calculations from 2015

Based on the comparison of indicators progression of the EU-15 and EU-10 countries in period 1996 - 2013, see Fig. 3 and 4, is obvious that both groups of EU countries already fully equated in the indicator "Political stability", where they are reaching the same level. The cause of this state is the significant decrease of value in the EU-15 countries during 1996 2013. Significant approximation of values was also observed in the indicator "Government effectiveness" and "Rule of law". This was caused on the contrary by the increase of the indicators value in the EU-10 countries in the observed period. In case of indicator "Voice and accountability", there was recorded low convergence between the EU-10 and EU-15 countries, also in the indicator "Regulatory quality". The EU-10 and EU-15 countries got slightly closer in values of indicator "Control of corruption", which was due to the smaller decreasing of value in the EU-15 countries and greater increase in indicator in the EU-10 countries. As documented by other research and scientific studies, for example Linhartová and Volejníková (2015) or Volejníková (2006), the area of corruption remains in the EU-10 insufficient and the increase of governance level in this area is for this countries not only the challenge for the future, but necessity.

\section{Conclusion}

The evaluation of the governance level in the EU was based on the comparison of the composite index of Good Governance in the EU-28 countries. The calculation of composite index was calculated from the aggregate indicators of Good Governance monitored by the World Bank. In the results, there are summarised the main outputs covering the evaluation of current state of governance and its progression in period 1996 - 2013 in the EU countries. The assessment of the current state of Good Governance in the EU countries shows that the composite index of Good Governance take only positive values in the interval from 0.12 to 1.85, which points out good condition of governance in the EU countries compared to the world economies average. There occur no negative values, but even values nearing the maximum 2.5. It results that the concept of Good Governance should be understood as a kind of ideal state of government, to which each country seeks by reform interventions and these efforts are mainly long-term. Inspirational character in the EU in terms of Good Governance practices has mainly leading countries (1 type, see Tab. 4.) as Finland, Sweden or Denmark. 
Within the research, there was verifying the hypothesis, whether the level of governance in the selected EU countries converge in the long term development. Based on the comparison of the composite index of Good Governance during 1996 - 2013 the trend of Good Government level progression is evident. While in the EU-10 countries the trend is rising in the EU-15 countries is declining. Specifically, in the case of the EU-10 countries the increase of composite Good Governance index by $15 \%$ was recorded (Fig.1). In summary it is possible to state that the convergence of the EU-10 countries to EU-15 countries proceeds relatively successfully. Countries are democratic and politically stable. Significant differences, either initial or final, are in the area of "Government effectiveness", "Regulatory quality" and "Rule of law". In the EU-10 countries the worst ranked indicator was "Control of corruption", which is the serious problem for all states.

Good Governance is regarded as a priority area in the EU. This is also evidenced by the European cohesion policy support in 2014 - 2020. The EU member states should therefore make use of the possibility to draw on financial resources from EU structural funds, which are intended to address the causes of low transparency and efficiency of public administration, high administrative and regulatory burdens and insufficient expertise of employees in the public administration, and help in this way to improve the level of public administration at national, regional and local levels.

\section{Acknowledgment}

This paper was supported within „Operational Programme Education for Competitiveness“ (Project No. CZ.1.07/2.3.00/20.0296).

\section{References}

[1] ARTURO, B. and S. CANTALE, 2012. The Value of Good Governance [online]. [vid. 15. October 2015]. Lausanne: IMD. Available from: www.imd.org/ research/challenges/upload/TC030-THE-VALUE-OF-GOOD-GOVERNANCE.pdf

[2] COUNCIL OF EUROPE, 2007. Recommendation CM/Rec(2007)7 of the Committee of Ministers to member states on good administration [online]. [vid. 25. May 2015]. Available from: wcd.coe.int/ViewDoc.jsp?id=1155877

[3] EUROPA, 2015. Jednotlivé země [online]. [vid. 2. May 2015]. Available form: http://europa.eu/about-eu/countries/index_cs.htm

[4] EUROPEAN COMMISSION, 2014. Promoting good governance - European Social Fund thematic paper. Luxembourg: Publications Office of the European Union. ISBN 978-92-79-35057-3.

[5] FRIČ, P., 2008. Světlé a stinné stránky neformálních sítí v postkomunistické společnosti. Sociologický časopis, 44(2), 295-320. ISSN 0038-0288.

[6] HALÁSKOVÁ, M. and R. HALÁSKOVÁ, 2015. The Structure and Financial Dimensions of Public Administration in EU Countries. Transylvanian Review of Administrative Sciences, 45E (June), 41-57. ISSN 2247-8310.

[7] JANN, W., M. RÖBER and H. WOLLMANN, 2006. Public management - Grundlagen, Wirkungen, Kritik. Berlin: Sigma. ISBN 3-89404-776-3.

[8] KAUFMANN, D., A. KRAAY and M. MASTRUZZI, 2006. Governance Matters V: Aggregate and Individual Governance Indicators for 1996-2005. World Bank Policy Research Working Paper [online]. No. 4012, 110 [vid. 2. June 2015]. Available from: siteresources.worldbank.org/DEC/Resources/GM5.pdf 
[9] KICKERT, W. J. M. et al., 1997. Managing complex networks- Strategies for the Public sector. London: Sage publications. ISBN 9780415459730.

[10] KLENK, T. and F. NULLMEIER, 2004. Public Governance als Reforms Strategie. Düsseldorf: Edition der Hans-Böckler-Stiftung 97. ISBN 3-935145-72-1.

[11] KLIMOVSKÝ, D., 2010. Genéza koncepcie good governance a jej kritické prehodnotenie v teoretickej perspektíve. Ekonomický časopis/Journal of Economics, 58(2), 188-205. ISSN 0013-3035.

[12] KOOIMAN, J., 2003. Governing as Governance. London: Sage. ISBN 0761940367.

[13] LACINA, K., 2010. Implementace principů "dobrého vládnutí" (Good Governance) a jejich efektivnost. Scientific Papers of the University of Pardubice, 14(16), 166-177. ISSN 1211-555X.

[14] LADI, S. 2008. Good Governance and Public Administration Reform in The Black Sea Economic Cooperation (Bsec) Member States. Xenophon Papers [online]. No. 6., 52 [vid. 17. October 2015]. Available from: icbss.org/media/110_original.pdf

[15] LINHARTOVÁ, V. and J. VOLEJNÍKOVÁ, 2015. Quantifying Corruption at a Subnational level. E\&M Economics and Management, XVIII(2), 25-38. ISSN 12123609.

[16] POTĚŠIL, L., 2008. Good Administration" in Scope of the Council of Europe. Veřejná správa, 12/2008(12), VII - VIII. ISSN 1213-6581.

[17] POTU゚ČEK, M. et. al., 2005. Veřejná politika. Praha: SLON. ISBN 80-86429-50-4.

[18] POTU゚ČEK, M, J. MUSIL and M. MAŠKOVÁ, 2008. Strategické volby pro českou společnost: teoretická východiska. Praha: Sociologické nakladatelství. ISBN 978-8086429-86-1.

[19] ROY, K. C. and C. A. TISDELL, 1998. Good Governance in Sustainable Development: the Impact of Institutions. International Journal of Social Economics, 25(6/7/8), 3101325. ISSN 0306-8293.

[20] VOLEJNÍKOVÁ, J., 2006. Možnosti hodnocení a měření korupce jako ukazatele kvality správy. In: Proceedings of International conference Veřejná správa 2006. Pardubice: Univerzita Pardubice, p. 476-481. ISBN 80-7194-882-9.

[21] VŠE, 2007-2013. Governance v kontextu globalizované společnosti a ekonomiky [online]. [vid. 15. October 2015]. Praha: VŠE. Available from: vz.fmv.vse.cz/dilcicile/cil-2-good-governance-\%e2\%80\%93-moderni-formy-vladnuti/

[22] WOHLFAHRT, N. and W. ZÜHLKE, 2005. Ende der kommunalen SelbstverwaltungZur politischen Steuerung im Konzern Stadt. Hamburg: VSA Verlag. ISBN 3-89965-1359.

[23] WORLD BANK, 2014. Worldwide Governance Indicators [online]. [vid. 25. May 2015]. Available from: info.worldbank.org/governance/wgi/index.aspx\#home

[24] WORLD ECONOMIC FORUM, 2014. The Global Competitiveness Report 2014-2015 [online]. [vid. 20. June 2015]. Cologny/Geneva: World Economic Forum. Available from: www3.weforum.org/docs/WEF_GlobalCompetitivenessReport_2014-15.pdf

[25] ZANGER, S. C., 2000. Good Governance and European Aid the Impact of Political Conditionality. European Union Politics, 1(3), 293-317. ISSN 1741-2757. 
[26] ŽÁK, M., 2005. Kvalita správy: hodnocení a měření. Working Paper CES VŠEM [online]. No. 13/2005 [vid. 12. June 2015]. ISSN 1801-2728. Available from: www.vsem.cz/data/data/ces-soubory/working-paper/gf_WPNo13.pdf

[27] ŽÁRSKA, E, T. ČERNĚNKO and D. KOZOVSKÝ, 2010. Verejná správa I. Bratislava: Ekonom. ISBN 978-80-225-3113-9. 